\title{
KESEHATAN REPRODUKSI MAHASISWA : KEBUTUHAN INFORMASI DAN PELAYANAN Studi Kualitatif di Jakarta Barat
}

\author{
Raditya Wratsangka ${ }^{1}$
}

\begin{abstract}
Background: Young people comprise students are a considerably large segment of the world population with important future roles, who face reproductive health-associated risks, such as sexually transmitted diseases, HIV/AIDS, sexual violence, unwanted pregnancy, and unsafe abortion. They are less informed, less experienced, and less comfortable in accessing reproductive health services and even face resistance from adults when attempting to do so.

Objective: To assess the reproductive health information, types, access and models of services required by students.

Method: This was a qualitative study involving students from three universities in West Jakarta. Data collection was by focus group discussion and indepth interviews. Data were validated by triangulation of information sources and method. Data analysis was performed by content analysis method to extract the root of the problem.

Result and Discussion: Fourteen unmarried students were involved as informants/respondents. Several had inadequate knowledge of reproductive health and difficulties in accessing appropriate information sources, so that they engaged in risky behavior for various reasons. The informants expressed their need for reliable information, accessible and friendly professional counselling and clinical reproductive health services, and also that guarantee their privacy.

Conclusion: Information, counselling and clinical services should be instituted that meet the requirements of students for improving their reproductive health.
\end{abstract}

Key words: reproductive health, information, counselling, services

\begin{abstract}
ABSTRAK
Latar Belakang: Kaum muda -termasuk mahasiswa- dengan populasi yang besar dan peran yang penting di masa depan, menghadapi berbagai risiko yang berkaitan dengan kesehatan reproduksinya, seperti: infeksi menular seksual, HIV/AIDS, kekerasan seksual, kehamilan yang tidak diinginkan dan aborsi yang tidak aman. Selama ini kaum muda kurang mendapatkan informasi, kurang berpengalaman, dan kurang nyaman mengakses pelayanan kesehatan reproduksi, bahkan mendapat tentangan dari kelompok dewasa, ketika mereka mencoba untuk memperoleh informasi dan pelayanan kesehatan reproduksi yang dibutuhkan.

Tujuan: Mendapatkan gambaran tentang informasi, jenis, akses dan model pelayanan kesehatan reproduksi yang dibutuhkan oleh mahasiswa.

Metode: Penelitian ini merupakan studi kualitatif dengan melibatkan mahasiswa dari 3 Universitas di Jakarta Barat. Pengumpulan data dilakukan dengan teknik diskusi kelompok terarah dan wawancara
\end{abstract}

1 Bagian Obstetri dan Ginekologi - Fakultas Kedokteran Universitas Trisakti /

Pusat Konseling, Informasi dan Edukasi Kesehatan Reproduksi Universitas Trisakti 
mendalam. Validasi data dilakukan dengan teknik triangulasi sumber informasi dan metode. Analisis data dilakukan dengan content analysis method untuk menggali akar permasalahan.

Hasil dan Pembahasan: Sebanyak 14 mahasiswa dilibatkan sebagai informan/responden yang semuanya belum menikah. Sebagian informan kurang pengetahuannya di bidang kesehatan reproduksi, mengalami kesulitan mengakses informasi dan sumber yang tepat, sehingga terlibat dalam perilaku berisiko. Para informan umumnya menyatakan kebutuhannya terhadap pelayanan konseling dan klinis kesehatan reproduksi yang profesional, mudah diakses, ramah dan tetap bisa menjaga privacy mereka.

Kesimpulan: Dibutuhkan pelayanan informasi, konseling dan klinis yang sesuai kebutuhan mahasiswa untuk meningkatkan kesehatan reproduksinya.

Kata kunci: kesehatan reproduksi, informasi, konseling, pelayanan

\section{PENDAHULUAN}

Berbagai hasil penelitian menunjukkan bahwa remaja/mahasiswa mempunyai permasalahan yang sangat kompleks, seiring dengan masa transisi yang dialami remaja. Masalah yang menonjol di kalangan remaja/mahasiswa antara lain seputar Triad Kesehatan Reproduksi Remaja (KRR), yaitu: seksualitas, infeksi Human Immunodeficiency Virus / Acquired Immuno Deficiency Syndrome (HIV/AIDS), serta penggunaan/konsumsi narkotik, alkohol, psikotropika dan zat adiktif lainnya (napza). ${ }^{1}$ Para remaja/mahasiswa ini dihadapkan pada lingkungan strategik yang berkembang dengan sangat cepat dan luas. Salah satu di antaranya adalah globalisasi informasi, yang kemudian tanpa disadari telah meliberalisasi dan merubah norma, etika dan moralitas agama, menjadi nilai-nilai kehidupan sekuler dengan berbagai dampaknya. Selain itu adanya komunikasi budaya dengan bangsa-bangsa lain dan pola hidup materialisme yang masuk akibat globalisme juga secara dramatis mengubah budaya tradisional dan struktur keluarga yang juga akan mengubah norma-norma perilaku seksual.

Selama masa remaja, orang-orang muda ini mengembangkan identitas orang dewasa, mereka bergerak ke arah fisik dan kedewasaan psikologis, dan berusaha untuk mandiri secara ekonomis.
Walaupun masa remaja secara umum adalah suatu periode yang sehat dalam kehidupan, yang diwarnai oleh pertumbuhan, perubahan, munculnya berbagai kesempatan, dan seringkali menghadapi risiko-risiko kesehatan reproduksi, akan tetapi justru banyak anak remaja sering kurang mendapatkan penerangan, kurang berpengalaman, dan kurang nyaman mengakses pelayanan kesehatan reproduksi (termasuk pelayanan kontrasepsi atau keluarga berencana) jika dibandingkan dengan orang dewasa. ${ }^{2,3}$ Kelompok remaja kadang mengalami kesulitan, bahkan tentangan dari kelompok dewasa, ketika mereka mencoba untuk memperoleh informasi dan jasa kesehatan reproduktif yang mereka butuhkan. Sehubungan dengan meningkatnya IMS dan kehamilan yang tidak diinginkan, para remaja dan kaum muda yang terlibat dalam aktivitas seksual di luar perkawinan akan menghadapi stigma sosial, konflik keluarga, permasalahan dengan institusi pendidikan, dan kebutuhan potensial untuk upaya pengguguran yang tidak aman dan pelayanan kesehatan lain yang dibutuhkannya. ${ }^{2}$

Penelitian ini merupakan studi kualitatif yang bertujuan untuk mendapatkan gambaran tentang pengetahuan dan perilaku kaum muda khususnya mahasiswa serta permasalahannya, termasuk kebutuhan informasi, edukasi dan 
model pelayanan kesehatan reproduksi yang diinginkan, yang hasilnya diharapkan dapat digunakan sebagai acuan untuk studi kuantitatif sebagai dasar dalam mencari model informasi, edukasi dan pelayanan kesehatan reproduksi yang sesuai bagi kaum muda.

\section{METODE}

Penelitian ini merupakan penelitian kualitatif dengan tujuan menggali informasi awal sebagai bahan membuat potret tentang pengetahuan, sikap dan perilaku mahasiswa yang berkaitan dengan kesehatan reproduksi (remaja/mahasiswa). Penelitian ini dilakukan pada bulan Oktober 2013, dengan populasi penelitian adalah mahasiswa dari 3 Universitas di Jakarta Barat yang dipilih secara acak. Pengumpulan data dilakukan dengan teknik diskusi kelompok terarah (DKT) atau focus group discussion (FGD) untuk kelompok pertama dan wawancara mendalam (WM) secara terpisah untuk kelompok kedua. Proses pemeriksaan keabsahan data menggunakan teknik triangulasi sumber informasi dan triangulasi metode. Data dan informasi yang sudah diperoleh diolah dengan diawali membuat transkripsi wawancara dan diskusi kelompok terarah. Pengolahan terhadap hasil transkripsi tersebut dilakukan dengan cara pengaturan terhadap informasi, dan pengkodean, serta meringkas informasi dalam bentuk matriks dan lain-lain sesuai dengan topik-topik pertanyaan yang diteliti dan diajukan. Analisis data dengan melihat isi dan kecenderungan data dan informasi yang telah diolah dalam bentuk matriks dengan menggunakan teknik content analysis untuk menggali akar permasalahan pemakaian teknik ini dilakukan dengan cara membuat matriks pembanding antara hasil wawancara mendalam dan hasil diskusi kelompok terarah. Hasil analisis isi dan kecenderungan data serta informasi inilah yang kemudian akan menjadi bahan pokok penulisan laporan akhir.

\section{HASIL DAN PEMBAHASAN}

\section{Karakteristik Informan/Responden}

Penelitian ini melibatkan 14 informan atau responden yang semuanya belum menikah, dan terbagi menjadi 2 kelompok, yaitu : kelompok pertama terdiri 10 mahasiswa semester 1-2, yang terdiri dari 2 laki-laki dan 8 perempuan. Mereka berusia berkisar antara 18-20 tahun, di antaranya 6 mahasiswa beragama Islam dan 4 mahasiswa beragama non-Islam (Kristen/ Katolik/Budha), semua tinggal serumah bersama orangtua mereka. Orangtua mereka kebanyakan bekerja sebagai wiraswasta, berpendidikan tinggi (S1 atau lebih tinggi), tapi ada 2 informan yang orangtuanya berpendidikan menengah (Sekolah Menengah Atas). Para mahasiswa informan sendiri tidak tahu berapa penghasilan bulanan orangtua mereka, tetapi setiap bulan mereka mendapat uang saku berkisar antara Rp 800 ribu 1,5 juta rupiah dari orangtua mereka. Sedangkan kelompok kedua terdiri dari 2 mahasiswa dan 2 mahasiswi semester 7-8, berusia antara 21-22 tahun. Tiga di antara keempat orang mahasiswa tersebut beragama Islam, dan 1 orang mahasiswi yang beragama Kristen. Pada umumnya mereka tinggal bersama orangtua masing-masing, dan hanya 1 orang mahasiswa yang tinggal di tempat kos karena orangtuanya tinggal di kota lain. Sebagian besar di antara mereka mempunyai orangtua yang berpendidikan tinggi (S1), bahkan salah satu di antara orangtua mereka ada yang berpendidikan Doktor (S3). Para remaja mahasiswa ini juga tidak ada yang tahu berapa penghasilan orangtua mereka dalam sebulan, tapi para remaja ini mendapat uang saku bulanan dari orangtua mereka sebesar antara Rp. 800 ribu hingga Rp 2 juta rupiah di luar biaya transpor tiap harinya. 


\section{Informasi yang Dikumpulkan dan Metode Pengumpulan Data}

\begin{tabular}{|c|c|c|c|}
\hline & \multirow[b]{2}{*}{ Informasi yang dikumpulkan } & \multicolumn{2}{|c|}{ Metode Pengumpulan Data } \\
\hline & & $\begin{array}{c}\text { Kelompok I: } \\
\text { Mahasiswa semester 1-2 } \\
-\quad 2 \text { laki-laki } \\
-\quad 8 \text { perempuan }\end{array}$ & $\begin{array}{c}\text { Kelompok II } \\
\text { Mahasiswa semester 7-8 } \\
-\quad 2 \text { laki-laki } \\
-\quad 2 \text { perempuan }\end{array}$ \\
\hline $\begin{array}{l}- \\
- \\
-\end{array}$ & $\begin{array}{l}\text { Pengetahuan, Sikap dan Perilaku } \\
\text { Mahasiswa di bidang Kesehatan } \\
\text { Reproduksi } \\
\text { Kebutuhan Mahasiswa terhadap } \\
\text { Informasi tentang Kesehatan } \\
\text { Reproduksi } \\
\text { Kebutuhan Mahasiswa tentang } \\
\text { Pelayanan Konseling dan Klinik } \\
\text { Kesehatan Reproduksi }\end{array}$ & $\begin{array}{l}\text { Diskusi Kelompok Terarah } \\
\text { (DKT) }\end{array}$ & $\begin{array}{l}\text { Wawancara Mendalam } \\
\text { (WM) }\end{array}$ \\
\hline
\end{tabular}

Pengetahuan, Sikap dan Perilaku Mahasiswa tentang Kesehatan Reproduksi:

Pengetahuan tentang Perubahan Fisik saat Pubertas

Kebanyakan informan tahu bahwa seorang pria dikatakan matang secara seksual bila sudah mengalami mimpi basah. Namun pemahaman ini bercampur dengan mitos bahwa kematangan seksual laki-laki juga ditandai dengan sudah dikhitan dan sudah pernah melakukan hubungan seksual. Beberapa orang informan menambahkan bahwa dada yang membesar, suara berubah, tumbuh kumis dan jakun merupakan tanda lain dari ciri kematangan seksual pada seorang pria. Sebagian kecil informan saja (perempuan) yang mengaku tidak tahu sama sekali ciri-ciri kematangan seksual laki-laki. Pengetahuan responden tentang ciri-ciri kematangan seksual perempuan ternyata cukup baik. Sebagian besar informan mengetahui bahwa ciri-ciri kematangan seksual perempuan ditandai dengan terjadinya menstruasi. Pemahaman ini pun bercampur dengan pemahaman yang tidak tepat serta mitos-mitos di masyarakat, seperti membesarnya payudara dan pinggul serta pengalaman berhubungan seksual sebagai ciri kematangan seksual.
Dari jawaban-jawaban yang diberikan informan tentang ciri kematangan seksual di atas dapat disimpulkan bahwa sebagian besar informan mempunyai cukup pengetahuan tentang ciri kematangan seksual laki-laki dan perempuan, hanya saja pemahaman ini bercampur dengan ciri-ciri kematangan sekunder lainnya (seperti tumbuhnya payudara dan jakun) dan mitos-mitos keliru yang menganggap pengalaman berhubungan seksual (baik pada lakilaki dan perempuan) sebagai tanda kematangan seksual. Dalam komponen Kesehatan Reproduksi Remaja (KRR) Survei Demografi dan Kesehatan Indonesia (SDKI) $2012^{5}$ yang respondennya adalah remaja berusia 15 - 24 tahun didapatkan hasil sebagai berikut: Perubahan fisik pada anak laki-laki yang paling sering disebutkan oleh responden perempuan adalah perubahan suara (69 persen dari perempuan), diikuti oleh pertumbuhan rambut di wajah, sekitar alat kelamin, ketiak, dada, kaki atau lengan (43 persen dari perempuan). Perubahan fisik pada anak laki-laki yang paling sering disebutkan oleh responden pria adalah pertumbuhan rambut di wajah, sekitar alat kelamin, ketiak, dada, kaki atau lengan (50 persen), kemudian diikuti 
oleh perubahan suara (49 persen). Perempuan lebih banyak daripada pria yang menyebutkan pertumbuhan jakun (masing-masing 53 persen dan 31 persen), sedangkan pria lebih banyak daripada perempuan yang menyebutkan mimpi basah (masing-masing 34 persen dan 30 persen).

\section{Pengetahuan tentang Masa Subur}

Pengetahuan informan mengenai masa subur perempuan dapat dikatakan kurang memadai. Sebagian besar menyebutkan masa subur dalam konteks 'waktu terjadinya' sehingga sebagian menyebutkan waktu seminggu sebelum atau sesudah menstruasi. Waktu terjadinya masa subur sendiri sulit untuk dipastikan karena siklus haid dan kondisi fisik individu yang berbeda-beda. Dari segi ilmu kebidanan, puncak kesuburan terjadi 14 hari sebelum hari haid berikutnya. Karena siklus haid pada perempuan tidak sama, maka masa subur terjadi 3-5 hari sebelum dan sesudah hari ke 14 tersebut (kurang lebih 10 hari di tengah suatu siklus haid). Berdasarkan waktu terjadinya masa subur, dapat dikatakan bahwa pengetahuan informan tentang masa subur sangat kurang, karena sebagian besar menjawab bahwa masa subur perempuan adalah "seminggu sesudah menstruasi". Hanya sebagian kecil informan yang tahu dengan benar bahwa masa subur perempuan adalah keluarnya sel telur dari indung telur (ovarium), dan sebagian lainnya ada yang menjawab "tidak tahu" tentang masa subur perempuan.

\section{Sumber Informasi tentang Pengetahuan Dasar Kesehatan Reproduksi}

Sebagian besar responden menyebut "teman" sebagai sumber informasi tentang pengetahuan dasar kesehatan reproduksi. Sisanya menyebutkan bahwa yang menjadi sumber informasi mereka adalah orangtua, guru (sewaktu mereka di sekolah menengah atas), media cetak dan elektronik, saudara dan instansi lainnya.
Peranan teman sebagai sumber informasi utama dapat dimaklumi karena peer group merupakan lingkungan yang paling dominan pengaruhnya bagi remaja/mahasiswa. Persoalannya adalah sejauh mana kebenaran informasi yang diperoleh dari teman. Hal ini menjelaskan terjadinya kesimpangsiuran pemahaman remaja tentang dasar-dasar kesehatan reproduksi. Terungkap juga kurangnya peran orangtua dalam memberikan informasi tentang kesehatan reproduksi kepada anak-anak mereka, termasuk lembaga-lembaga yang diharapkan berperan memberikan informasi tentang kesehatan reproduksi, misalnya petugas Puskesmas dan lembaga-lembaga swadaya masyarakat. Secara keseluruhan, pengetahuan dasar informan tentang kesehatan reproduksi tidak memadai. Hal ini diduga karena dominasi peer group yang tidak memiliki pengetahuan yang baik tentang kesehatan reproduksi dan gencarnya informasi, terutama melalui media cetak mengenai seks secara tidak proporsional sebagai sumber informasi. Dalam komponen KRR SDKI 20125, responden perempuan ditanya apakah mereka mendiskusikan dengan orang lain tentang haid sebelum mereka mengalami haid yang pertama. Hasil SDKI 2012 tersebut menunjukkan bahwa lebih dari setengah perempuan membicarakan hal tersebut dengan teman (53 persen) atau dengan ibunya (41 persen). Satu dari empat perempuan tidak mendiskusikan tentang haid dengan orang lain sebelum mengalami haid yang pertama. Responden pria ditanya tentang pengalaman mereka tentang mimpi basah, termasuk diskusi mengenai mimpi basah dengan orang lain sebelum hal tersebut terjadi. Pria lebih tidak suka mendiskusikan tentang pengalaman perubahan fisik yang terjadi pada masa pubertasnya dibandingkan wanita. Hasil SDKI 2012 menunjukkan bahwa setengah dari pria (50 persen) tidak membicarakan dengan orang lain dan hampir setengah dari pria (48 persen) membicarakannya dengan teman. 


\section{Pengetahuan tentang Metode dan Tempat Pelayanan Kontrasepsi}

Para informan diminta untuk menyebutkan semua metode kontrasepsi yang pernah mereka dengar. Untuk metode yang tidak disebutkan, pewawancara menjelaskan deskripsi metode tersebut dan bertanya apakah informan pernah mendengarnya. Sebagian besar informan mengatakan pernah tahu tentang setidaknya satu metode kontrasepsi, terutama kondom dan pil. Hasil SDKI $2012^{9}$ menunjukkan bahwa 95 persen dari remaja wanita dan 93 persen dari remaja pria pernah mendengar setidaknya satu metode kontrasepsi. Pengetahuan tentang metode kontrasepi modern di antara remaja belum kawin di Indonesia telah tersebar luas. Secara keseluruhan, wanita mempunyai pengetahuan lebih baik dibanding pria tentang cara untuk mencegah kehamilan dengan menggunakan metode kontrasepsi modern (95 persen dibanding 93 persen). Remaja belum kawin di Indonesia kurang mengenal metode kontrasepsi tradisional. Secara rata-rata wanita mengetahui lima metode, sedangkan pria mengetahui empat metode. Metode kontrasepsi yang paling populer di kalangan responden wanita adalah pil KB $(90$ persen) dan suntikan KB (89 persen). Delapan dari sepuluh wanita tahu tentang kondom (80 persen). Seperti yang diperkirakan, metode yang paling umum dikenal oleh responden pria adalah kondom (89 persen). Pengetahuan tentang pil KB dan suntikan KB juga tinggi di antara responden pria (masing-masing sebesar 82 persen dan 66 persen).

\section{Perilaku Risiko}

Sebagian besar responden menyatakan pernah berpacaran atau sedang berpacaran. Mengenai perilaku berpacaran sangat bervariasi, ada yang hanya mengobrol saja sambil pergi makan atau menonton film bersama di bioskop. Ada juga yang sudah melakukan tindakan yang "berani", misalnya mencium leher (necking), ada yang meraba-raba anggota badan sampai menggesek-gesekkan alat kelamin (petting), tapi ada 3 informan sudah melakukan hubungan seksual meskipun mengaku belum lama berpacaran.

Perilaku seksual pranikah di kalangan remaja cukup memprihatinkan, diperkuat dengan data dari Depkes Tahun 2009 di 4 kota besar (Medan, Jakarta Pusat, Bandung dan Surabaya), menunjukkan bahwa 35,9\% remaja mempunyai teman yang sudah pernah melakukan hubungan seks pranikah dan 6,9\% responden telah melakukan hubungan seks pranikah. Berdasarkan penelitian dari Australian National University (ANU) dan Pusat Penelitian Kesehatan Universitas Indonesia tahun 2010 di Jakarta, Tangerang dan Bekasi (JATABEK) dengan jumlah sampel 3006 responden (usia <17 - 24 tahun), menunjukkan bahwa $20,9 \%$ remaja mengalami kehamilan dan kelahiran sebelum menikah dan $38.7 \%$ remaja mengalami kehamilan sebelum menikah dan kelahiran setelah menikah. Dari data tersebut terdapat proporsi yang relatif tinggi pada remaja yang melakukan pernikahan disebabkan oleh kehamilan yang tidak diinginkan. ${ }^{1}$

Menonton film porno, membaca buku dan melihat gambar porno sangat menimbulkan hasrat untuk berhubungan seksual. Sementara itu paparan informasi dewasa ini memperluas akses remaja terhadap pornografi dalam berbagai bentuk medianya. Hampir separuh dari informan, yang semuanya laki-laki, pernah melakukan onani/masturbasi, ada yang 1-2 kali seminggu dan ada yang hanya 1 kali sebulan.

\section{Pengetahuan tentang Penularan IMS dan HIV/ AIDS}

Pada penelitian ini, jenis IMS yang paling dikenal remaja adalah infeksi HIV/AIDS. Sebagian besar sudah mengenal penyakit ini, sedangkan jenis penyakit menular seksual yang lain adalah 
sifilis dan gonore. Hanya sedikit informan yang mengetahui jenis-jenis infeksi menular seksual lain, seperti Herpes genitalis, kutil kelamin dan kutu kelamin.

Dalam DKT dan WM, terungkap bahwa ada di antara teman-teman mereka yang pernah terkena IMS, tapi mencoba mengobatinya sendiri dulu sebelum akhirnya pergi ke dokter karena tidak sembuh. Ada juga informan yang tidak tahu banyak tentang IMS, tapi hanya sebatas pernah mendengar nama penyakitnya saja :

"Kalau tentang sipilis dan AIDS, saya cuma sekedar pernah denger aja. Katanya sih memang berbahaya. Biasanya yang kena tuh cowok-cowok yang suka ke hotel dan main sama perempuan bayaran atau PSK. Namanya PSK itu kan pasti gak bersih. Kita hindarin deh pergi ke tempat-tempat begituan. Sifilis, AIDS itu karena kelakuan seks bebas. Kalau terpaksa bisa aja mencegah dengan cara pakai kondom."

Pengetahuan informan tentang cara penularan IMS cukup baik, namun banyak pula pendapat yang salah seputar penularan IMS. Sebagian besar informan menyatakan penularan bisa terjadi melalui hubungan seksual, penggunaan jarum suntik bergantian, transfusi darah serta dari ibu hamil kepada janin dalam kandungannya. Sementara itu masih ada pula pendapat keliru bahwa bersentuhan dengan penderita dan menggunakan toilet/kamar mandi yang sama dengan penderita dapat menularkan IMS.

Pengetahuan tentang cara pencegahan IMS dan HIV/AIDS masih bercampur antara pengetahuan yang benar dengan mitos-mitos yang ada dan keliru. Sebagian besar informan menjawab tidak melakukan hubungan seks, tapi sebagian lain menyatakan bahwa cara pencegahan adalah dengan menggunakan kondom saat melakukan hubungan seks. Namun masih ada responden yang menganggap bahwa minum antibiotik, minum jamu dan mencuci alat kelamin dapat mencegah penularan IMS dan HIV/ AIDS. Padahal mengkonsumsi antibiotika secara sembarangan sangat berbahaya karena dapat mengakibatkan resistensi kuman.

Sumber informasi tentang IMS dan HIV/ AIDS sebagian besar justru berasal dari media cetak dan elektronik. Beberapa surat kabar atau media cetak membuka kolom konsultasi remaja yang banyak membahas tentang IMS dan HIV/ AIDS, selain itu beberapa stasiun radio juga mempunyai acara-acara yang berisi tanya jawab seputar masalah kesehatan reproduksi, IMS dan HIV/AIDS. Peranan teman sebagai sumber informasi cukup dominan. Orangtua, guru dan lembaga-lembaga yang ada (termasuk lembaga swadaya masyarakat) kurang dominan berperan sebagai sumber informasi tentang IMS dan HIV/ AIDS bagi remaja.

\section{Pengetahuan dan Pendapat terhadap Aborsi}

Sebagian besar informan berpendapat bahwa aborsi adalah tindakan yang sangat berdosa karena tidak sesuai dengan ajaran agama dan tidak berperikemanusiaan. Sebagian kecil responden ada yang berpendapat bahwa aborsi boleh saja dilakukan dalam keadaan terpaksa dan terserah kepada yang menjalani. Ada informan yang mengatakan :

"Saya nggak setuju abortus karena itu sama dengan membunuh, dan itu berarti dosa karena melanggar norma. Bayi itu kan makhluk hidup juga ciptaan Allah"

Ada informan lainnya yang mengatakan :

"Nggak setuju, sebab manusia yang ada di dalam kandungan itu juga punya hak hidup, karena itu jika aborsi sudah dosa. Belum lagi bahayanya bagi si ibu, katanya ada yang sampai meninggal waktu diaborsi" 
Tapi ada juga informan yang mengatakan :

"Tergantung pengguguran kandungan itu motifnya apa? Kalau akan lebih banyak untuk kebaikan ibunya, mengapa tidak?Apalagi kalau ibunya belum siap atau sakit berat, daripada bayinya gak terurus nantinya"

Dari hasil DKT dan WM terungkap bahwa yang dimaksud dengan keadaan terpaksa berkaitan dengan alasan kesehatan, misalnya kalau kehamilan diteruskan maka akan dapat membahayakan jiwa si ibu. Namun hasil WM, terungkap bahwa ada teman mereka yang melakukan aborsi karena dipaksa oleh pacar atau pasangannya, atau ada juga yang melakukan aborsi karena hubungan pasangan tersebut tidak disetujui oleh kedua orangtuanya. Selain itu ada pula yang melakukan aborsi karena merasa malu dan masih ingin melanjutkan sekolah.

Para siswa yang hamil di negara-negara berkembang seringkali mencari cara untuk melakukan aborsi untuk menghindari kemungkinan dikeluarkan dari sekolah. Di negara-negara di mana aborsi adalah ilegal atau dibatasi oleh ketentuan usia, para perempuan muda ini mungkin akan mencari penolong ilegal yang mungkin tidak terampil atau berpraktik di bawah kondisi-kondisi yang tidak bersih. Aborsi yang tidak aman menempati proporsi tinggi dalam kematian ibu di antara para remaja. Di Indonesia diperkirakan setiap tahun terjadi sekitar 2,3 juta kasus aborsi, dan angka aborsi di kalangan remaja (15-24 tahun) mencapai 700-800 ribu kasus per tahun. Kementerian Kesehatan memperkirakan bahwa angka aborsi mencapai $11 \%$ di antara beberapa penyebab kematian maternal di Indonesia. ${ }^{6,7,8}$

\section{Pendapat tentang Hubungan Seks sebelum Menikah}

Hubungan seks sebelum menikah bisa berakibat terjadinya kehamilan yang tidak diinginkan (KTD), aborsi dan penularan IMS. Sebagian besar informan tidak setuju dengan hubungan seksual pranikah. Kebanyakan menganggap bahwa hubungan seksual pranikah adalah perbuatan dosa atau haram. Namun ada pula informan yang setuju dilakukannya hubungan seksual sebelum menikah asalkan dilakukan atas dasar suka sama suka, dilakukan dengan pacar atau sudah merencanakan untuk menikah.

Menurut sebagian besar informan, alasan orang melakukan seks pranikah adalah karena pengaruh lingkungan. Sebagian informan juga berpendapat bahwa orang melakukan seks pranikah untuk membuktikan cintanya kepada pacarnya. Sisanya menyatakan bahwa hal tersebut dilakukan karena tidak taat kepada agama, tidak ada bimbingan dan pengawasan dari orangtua, karena kebutuhan biologis dan karena pengaruh lingkungan, termasuk lingkungan pergaulan di luar sekolah.

Dalam komponen KRR SDKI $2012^{5}$, responden ditanya bagaimana pendapat dan praktek dalam perilaku seksual. Penerimaan responden terhadap perilaku hubungan seksual pranikah sangat rendah. Secara umum, persentase wanita yang menyetujui hubungan seksual pranikah lebih sedikit daripada pria. Hanya $1 \%$ dari responden wanita dan $4 \%$ dari responden pria yang menyatakan wanita boleh melakukan hubungan seksual sebelum menikah. Stigmanya, kecenderungan pria untuk melakukan hubungan seksual pranikah lebih sedikit daripada wanita; sebanyak $2 \%$ dari wanita dan $7 \%$ dari pria, menyatakan bahwa mereka menyetujui pria yang melakukan hubungan seksual sebelum menikah.

Responden komponen KRR SDKI $2012^{9}$ juga ditanya tentang pengalaman seksual mereka. Secara umum, hanya $1 \%$ dari responden wanita yang mengaku pernah melakukan hubungan seksual. Pria yang pernah melakukan hubungan seksual lebih tinggi daripada wanita (8 persen). Terlihat sedikit perbedaan dalam pengalaman seksual diantara wanita menurut umur. 
Responden pria yang lebih tua cenderung lebih memiliki pengalaman seksual dibanding pria lainnya (15 berbanding dengan 5 persen).

\section{Kebutuhan Remaja terhadap Media Informasi}

Pada penelitian ini, dari hasil wawancara mendalam dan diskusi kelompok terfokus diketahui bahwa jenis media yang paling banyak digunakan para remaja adalah internet, televisi, diikuti oleh radio dan sebagian kecil lebih suka membaca majalah, koran maupun buku. Disini jelas terlihat bahwa remaja lebih senang menonton/melihat (visual) daripada membaca atau mendengar, sedangkan waktu yang paling banyak untuk menggunakan media informasi adalah sore dan malam hari sesudah jam sekolah kuliah berlalu.

Dari hasil wawancara diketahui pula bahwa acara radio yang paling disukai informan adalah talk show dan musik, sehingga acaranya tidak membosankan. Acara lain yang juga digemari informan adalah acara interaktif dimana pendengar bisa menghubungi stasiun radio melalui pesawat telpon untuk berbincang atau berkonsultasi dengan pengisi acara atau narasumber pada acara tersebut.

\section{Pandangan tentang Pusat Pelayanan Kesehatan Reproduksi Mahasiswa}

Dari wawancara yang dilakukan diketahui bahwa informan selalu ingin mengatasi persoalan yang dihadapi seorang diri lebih dulu. Jika mereka merasa tidak mampu mengatasi persoalan yang dihadapi, maka paling banyak meminta bantuan kepada teman. Kendalanya adalah bahwa teman sebaya mempunyai pengetahuan yang sama terbatasnya, sehingga seringkali timbul masalah baru yang tidak diharapkan sebelumnya. Sebagian kecil responden ada yang berkonsultasi dengan orangtua mereka, atau dengan saudara. Tidak satupun informan yang berkonsultasi dengan dosennya sesudah mereka menjadi mahasiswa. Dari gambaran tersebut jelaslah bahwa para mahasiswa pada umumnya belum menemukan tempat yang tepat atau adekuat untuk memecahkan dan mencari jalan keluar masalah kesehatan reproduksi mereka.

Di antara para informan ada pula sebagian kecil yang juga berkonsultasi dengan lembaga yang khusus membantu menangani remaja. Kecilnya jumlah ini disebabkan karena masih kurangnya upaya pengenalan dan promosi yang dilakukan oleh Pusat Pelayanan Remaja/ Mahasiswa.

Jenis pelayanan yang paling dibutuhkan oleh kebanyakan informan adalah konsultasi psikologis. Selain itu juga dirasakan adanya kebutuhan informasi tentang masalah remaja dan juga pelayanan medis. Kebutuhan akan jenis-jenis pelayanan seperti penyuluhan dan pelatihan/training, pengembangan hobi dan persiapan karir serta konsultasi agama pun ternyata dirasakan oleh para informan.

Pengelola pusat pelayanan remaja yang disukai oleh para informan adalah tenaga profesional, seperti psikolog, dokter dan lainlain. Selain itu sebagian informan juga menyukai kalau pengelolanya adalah orang dewasa yang berjiwa muda, serta diharapkan untuk melibatkan mahasiswa itu sendiri. Sedangkan guru/dosen dan orangtua bukanlah pengelola ideal menurut mereka, hal ini terbukti dengan tidak satupun informan yang memilih dosen dan orangtua sebagai pengelola pusat pelayanan remaja/mahasiswa.

Lokasi yang disukai dan dianggap ideal oleh sebagian besar informan bagi pusat pelayanan kesehatan reproduksi remaja adalah yang memiliki aksesibilitas yang mudah dicapai, ada sebagian informan yang berpendapat pusat pelayanan remaja itu ada di kampus, tapi ada juga yang menginginkan lokasinya di daerah perumahan atau dekat pasar.

Tata ruang yang dianggap ideal bagi sebuah pusat pelayanan kesehatan reproduksi 
mahasiswa yang terpenting adalah masalah kebersihan secara keseluruhan. Tata ruang yang baik harus dapat memberikan rasa nyaman kepada para pengelola untuk bekerja dan juga dapat membuat remaja/mahasiwa yang datang senang berkunjung dan merasa nyaman dan betah (youth friendly and comfortable) berada di pusat pelayanan remaja tersebut. Diharapkan agar ruangan dapat diatur secara apik, tidak dipadati kursi, melainkan lantainya cukup ditutup dengan karpet, sehingga para mahasiwa dapat duduk dengan santai sambil berdiskusi, membaca dan sebagainya.

Ruangan konsultasi sebaiknya dibuat tersendiri, dengan pintu yang dapat ditutup sehingga menjamin kerahasiaan mahasiwa yang berkonsultasi serta dilengkapi dengan pesawat telpon. Ruangan pelayanan medis sebaiknya terpisah. Dinding sebaiknya dicat dengan warnawarna lembut agar tercipta suasana damai dan sesuai dengan selera mahasiswa. Sirkulasi udara perlu diperhatikan supaya ruangan tidak pengap. Walaupun tidak menggunakan AC, namun paling tidak tersedia kipas angin.

\section{KESIMPULAN DAN SARAN}

Kelompok kaum muda termasuk mahasiswa dengan populasi yang cukup besar dan peran yang penting di masa depan, menghadapi berbagai risiko yang berkaitan dengan kesehatan reproduksinya, seperti: infeksi menular seksual (IMS), HIV/AIDS, kekerasan seksual, kehamilan yang tidak diinginkan dan aborsi yang tidak aman, sehingga mereka perlu mendapat informasi yang tepat dan mudah diakses. Dengan demikian diharapkan para mahasiswa memiliki informasi yang benar dan sesuai kebutuhan, sehingga dapat menghindari perilaku berisiko. Program yang ditujukan untuk meningkatkan kesehatan reproduksi mahasiswa perlu memahami risikorisiko ini dan mempertimbangkan berbagai faktor yang mempengaruhi kehidupan mereka sebagai mahasiswa. Dibutuhkan sarana atau media informasi yang mudah diakses, program pelayanan konseling dan klinis yang sesuai untuk mahasiswa, serta sikap petugas yang ramah dan mau memperhatikan kebutuhan, keprihatinan, pemahaman serta kenyamanan mereka, bahkan melibatkan mereka dalam kegiatan perancangan dan pelaksanaan program. Dukungan dan kerjasama orangtua, institusi pendidikan, kelompok masyarakat dan tokoh agama sangat dibutuhkan dalam berbagai upaya perancangan, pelaksanaan, evaluasi maupun pengembangan program peningkatan kesehatan reproduksi mahasiswa.

\section{DAFTAR PUSTAKA}

1. Badan Kependudukan dan Keluarga Berencana Nasional. Pedoman Pengelolaan Pusat Informasi dan Konseling Remaja dan Mahasiswa (PIK R/M). Jakarta, 2012.

2. World Health Organization (WHO). Promoting and safeguarding the sexual and reproductive health of adolescents. Reproductive Health Research. 2005.

3. World Health Organization. Growing in Confidence: Programming for adolescent health and development. 2002.

4. Miles MB, Huberman AM, Saldana J. Qualitative Data Analysis: A Method Sourcebook, $3^{\text {rd }}$ edition. Arizona State University, Sage Publications Inc, 2014.

5. Biro Pusat Statistik (BPS), Badan Kependudukan dan Keluarga Berencana Nasional (BKKBN), Kementerian Kesehatan. Survei Demografi dan Kesehatan Indonesia 2012 : Kesehatan Reproduksi Remaja (Laporan Pendahuluan), 2013.

6. Waspodo D. Kesehatan Reproduksi Remaja. Dalam: Martaadisoebrata D., Sastrawinata S., Saifuddin AB., (eds). Bunga Rampai Obstetri dan Ginekologi Sosial. Yayasan Bina Pustaka Sarwono Prawirohardjo. Jakarta, 2005.

7. World Health Organization. Towards adulthood: Exploring the sexual \& reproductive health of adolescents in South East Asia. 2003.

8. World Health Organization. Sexually Transmitted Infections: Issues in Adolescent Health and Development. WHO Discussion Papers on Adolescence. 2005 